\title{
Penggunaan Google Classroom Bagi Guru Sekolah Dasar Negeri 170 Palembang Sebagai Platform Pembelajaran Daring di Masa Pandemi Covid-19
}

\author{
Guntoro Barovih*1, Muhammad Ridho Ardiansyah², Deli Abdurunnapis Hutanegara3 \\ ${ }^{1,3}$ Program Studi Informatika, STMIK PalComTech Palembang \\ ${ }^{2}$ Program Studi Sistem Informasi, STMIK PalComTech Palembang \\ *e-mail: guntoro@palcomtech.ac.id ${ }^{1}$, ridho_ardiansyah@palcomtech.ac.id ${ }^{2}$, Abdurunnapisdeli@gmail.com³
}

\begin{abstract}
Indonesia is currently facing the Covid-19 pandemic situation, where we are entering the New Normal stage. This New Normal stage changes the process of educational activities, conventional education is changed to New Normal era education. New Normal era education in the implementation of learning involves the use of technology, technology in delivering material to students in their respective educational units. The Ministry of Education and Culture of Indonesia officially conveys on the official website kemdikbud.go.id about Guidelines for the Implementation of Learning in the Academic Year and the New Academic Year in the New Normal Period. yellow, orange, and red zones are prohibited from conducting face-to-face learning in education units. Education units in these zones continue to learn by learning from home. This community service for SD Negeri 170 Palembang teachers aims to introduce the Google Classroom application as a means of supporting learning activities. The method in this service activity is training. The results obtained from this training activity on the use of Google Classroom are that it can increase teachers' understanding of technology that can be utilized optimally in conducting teaching and learning activities.
\end{abstract}

Keywords: Google Classroom, online learning, Study from home

\begin{abstract}
Abstrak
Indonesia saat ini sedang menghadapi situasi pandemi Covid-19, dimana kita memasuki tahap New Normal. Tahap New Normal ini mengubah proses kegiatan pendidikan, pendidikan yang bersifat konvensional diubah menjadi pendidikan era New Normal. Pendidikan era New Normal dalam penyelenggaraan pembelajarannya melibatkan penggunaan teknologi, teknologi dalam penyampaian materi ke siswa didik dalam satuan pendidikan masing-masing. Kementerian Pendidikan dan Kebudayaan Indonesia secara resmi menyampaikan di laman resmi kemdikbud.go.id tentang Panduan Penyelenggaraan Pembelajaran pada Tahun Ajaran dan Tahun Akademik Baru di Masa New Normal Dimana kegiatan penyelenggaraan pembelajaran disesuaikan dengan status zona daerah kegiatan pembelajaran dilakukan, untuk daerah yang berada di daerah zona kuning, oranye, dan merah dilarang melakukan pembelajaran tatap muka di satuan pendidikan. Satuan pendidikan pada zona-zona tersebut tetap melanjutkan pembelajaran dengan cara belajar dari rumah. Pengabdian masyarakat untuk guru SD Negeri 170 Palembang ini bertujuan untuk memperkenalkan aplikasi Google Classroom sebagai sarana pendukung kegiatan pembelajaran. Metode dalam kegiatan pengabdian ini adalah pelatihan. Adapun hasil yang didapat dari kegiatan pelatihan penggunaan Google Classroom ini yaitu dapat menambah pemahaman bagi guru-guru tentang teknologi yang dapat dimanfaatkan dengan maksimal dalam menyelenggarakan kegiatan belajar mengajar.
\end{abstract}

Kata kunci: Google Classroom, pembelajaran daring, Belajar dari rumah

\section{PENDAHULUAN}

Pada tahun ajaran baru 2020/2021 tepatnya bulan Juli 2020 masih diberlakukan konsep pembelajaran Belajar dari Rumah untuk daerah yang masuk ke dalam daerah zona kuning, oranye dan merah bagi jenjang pendidikan Sekolah Dasar(Angraini 2020), Sekolah Menengah Pertama dan Sekolah Menengah Atas. Hal ini disampaikan secara resmi oleh Menteri Pendidikan dan Kebudayaan Indonesia Bapak Nadiem Makarim di laman resmi kemendikbud.go.id (Kemdikbud 2020). Sehingga pemerintah melakukan berbagai upaya untuk menekan tingkat penyebaran covid-19, tidak terkecuali pada sisi kegiatan Pendidikan. Pemerintah melakukan upaya dengan memberlakukan pembelajaran sepenuhnya dilakukan dari rumah mulai dari Pendidikan usia dini hingga perguruan tinggi (Amalina 2020; Ratu, Uswatun, and Pramudibyanto 2020). 
SDN 170 merupakan salah satu Pendidikan usia dini yang berada pada naungan dinas Pendidikan kota Palembang yang terdampak pada pandemic dimana kegiatan belajar harus dilakukan dari rumah. SDN 170 satu semester sebelumnya metode pembelajaran menggunakan konsep Belajar dari Rumah, dimana siswa diberikan tugas oleh guru dan dikumpul kembali oleh siswa melalui media online seperti e-mail, dan Whatsap. Siswa SD adalah siswa yang belum sepenuhnya bisa mandiri dalam proses pembelajaran sehingga dalam satu semester yang telah berjalan proses pembimbing belajar ini diserahkan langsung kepada orang tua masing-masing. Permasahan yang dihadapi oleh orang tua siswa adalah tidak semua orang tua siswa paham materi yang akan disampaikan kepada anaknya masing-masing, hal ini karena berdasarkan latar belakang pendidikan orang tua yang beragam.

Proses pembelajaran di kelas sebenarnya bisa dilakukan secara online dengan menggunakan aplikasi conference. Ada banyak platform yang dapat digunakan oleh para guru seperti Google Classroom, Zoom, kahoot, Quizlet, cisco webex dan lain-lain (Sri Harini Ekowati et al. 2020). Dengan teknologi tersebut guru dapat menyampaikan materi langsung ke peserta didiknya tanpa harus hadir ke sekolah, cukup guru dan anak didik berada di rumah masingmasing dengan ditemani orang tua. Untuk pembelajran pada SDN 170 dapat menggunakan Teknologi conference seperti Google Classroom yang dapat berjalan pada perangkat komputer dan smartphone yang terkoneksi dengan internet, dan yang paling penting juga Google Classroom tersedia versi gratisnya juga, walaupun ada beberapa batasan dari jumlah peserta dan waktu tapi masih dirasakan cukup untuk diterapkan dalam proses penyampaian materi di SD Negeri 170 Palembang.

Google classroom merupakan suatu perangkat lunak pembelajaran atau biasa disebut sebagai E-learning yaitu kelas virtual atau kelas online yang sangat memungkinkan para peserta bisa berkomunikasi satu sama lain, melihat presentasi atau video dan terlibat dalam suatu kelompok kerja(Gunawan and Sunarman 2017; Wong 2020). Perangkat lunak google classroom saat ini sudah banyak digunakan oleh para guru sebagai upaya peningkatan kopetensi para guru dalam merespon berbagai kondisi belajar seperti saat ini pada masa pandemic (Kurniawan, Purnomo, and . 2020). Google classroom tidak hanya digunakan untuk meningkatkan kopetensi guru tetapi juga digunakan sebagai media untuk meningkatkan antusia belajar mandiri bagi siswa hingga mahasiswa(Ali and Zaini 2020; Santosa, Negara, and Samsul Bahri 2020)

Dari hasil wawancara dengan Kepala sekolah Sekolah Dasar Negeri 170 Pembelajaran secara online dengan menggunakan teknologi seperti Google Classroom adalah kegiatan pembelajaran yang belum pernah dilakukan sivitas Sekolah Dasar Neger 170 sehingga perlu dilakukan pelatihan terlebih dahulu baik bagi guru dan siswa didik. Dalam pengabdian masyarakat ini difokuskan terlebih dahulu pelatihan penggunaan aplikasi Google Classroom kepada guru yang diharapkan secara berkala, guru dapat menyampaikan dan membimbing siswa juga dalam penggunaan aplikasi Google Classroom, sehingga baik guru dan siswa akan terbiasa dengan pembelajaran online ini.

Tujuan dari pelaksanaan program pengabdian masyarakat ini adalah untuk memberikan pengetahuan dan keterampilan bagi guru SD Negeri 170 Palembang tentang penggunaan aplikasi Google Classrooming sebagai sarana pendukung pembelajaran dari rumah kondisi New Normal. Serta manfaat yang didapat dari pelaksanaan program pengabdian ini adalah bagi peserta bisa memperoleh tambahan pengetahuan dan keterampilan dalam menggunakan Aplikasi Google Classroom sebagai sarana pendukung kegiatan pembelajaran sekolah dari rumah saat kondisi New Normal.

\section{METODE}

Kegiatan pengabdian ini menggunakan metode pelatihan. Meotde pelatihan ini dipilih karena dirasakan lebih efektif untuk mendapatkan keahlian secara cepat jika dibandingkan dengan metode pendampingan pelatihan dilakukan dengan berbagai kegiatan yaitu sosialisasi 
manfaat google classroom, pretest, proses instalasi google classroom, membuat tugas dan submit tugas dan terakhir adalah melakukan evaluasi post-test.

Guna mensukseskan kegiatan pengabdian ini yang dilaksanakan oleh STMIK Palcomtech, maka SDN 170 Palembang selaku mitra pengabdian, berperan aktif memalui :

a. Mengundang para guru untuk bisa hadir dalam kegiatan pengabdian masyarakat yang dilaksanakan

b. Menyediakan ruang untuk kegiatan pengabdian.

c. Memberikan fasilitas akses internet dalam mensupport kegiatan pengabdian ini, dikarenakan google classroom menggunakan media pengaksesan internet secara langsung.

Langkah-langkah yang akan dilakukan untuk mencapai solusi dalam mengatasi permasalahan mitra antara lain sebagai berikut, pertama sosialisasi mengenai kegiatan Pengabdian kepada Masyarakat yang dihadiri oleh tim pengusul dan mitra (Guru dan Kepala Sekolah SD Negeri 170 Palembang). Tahap sosialisasi ini akan disampaikan informasi mengenai latar belakang, tujuan dan target yang ingin dicapai dari kegiatan PKM ini dan melakukan pretest untuk mengetahui tingkat pemahaman dan pengetahuan para guru tentang informasi E-learning yang digunakan dalam proses belajar secara online. Pretest digunakan untuk mengetahui sejauh mana materi atau bahan pelajaran yang akan diajarkan telah dapat di kuasai(Effendy 2016)

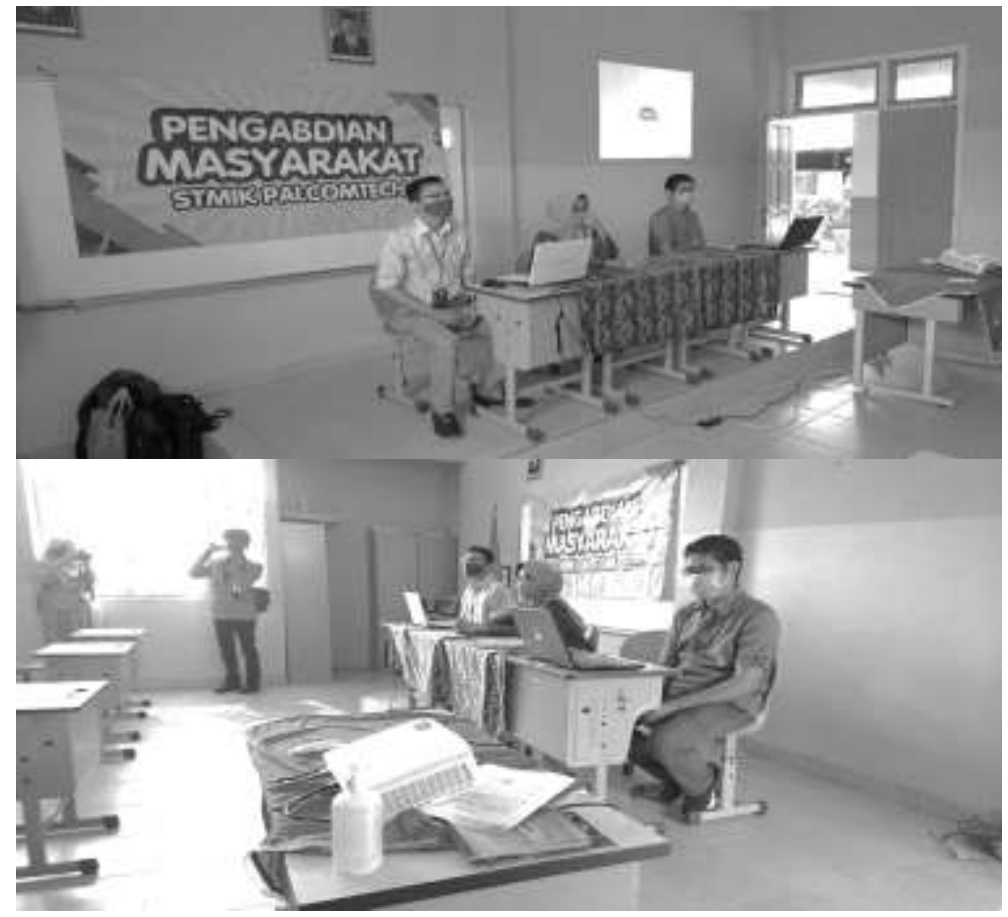

Gambar 1. Sosialisasi dengan Guru SD N 170 Palembang

Pendampingan mengenai cara instalasi dan penggunaan aplikasi Google Classroom dilakukan oleh mahasiswa dengan bimbingan Bapak Guntoro Barovih, S.Kom., M.kom. dan Bapak Muhammad Ridho Ardiansyah ,S.Kom., M.Kom. 


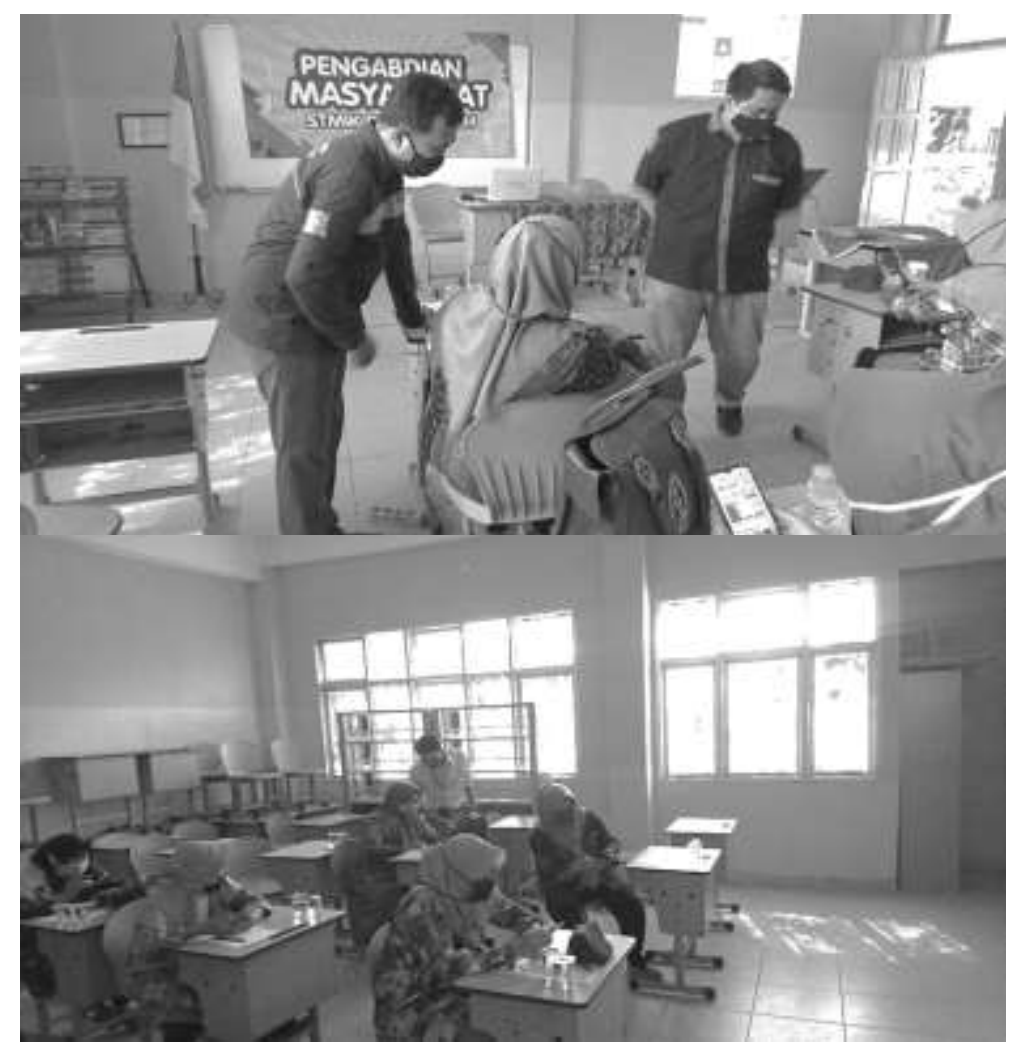

Gambar 2. Kegiatan instalasi aplikasi

Pada tahap akhir dilakukan evaluasi untuk mengukur keberhasilan kegiatan yang telah dilakukan dengan menyebar kuesioner kepada peserta dalam bentuk post-test. Post-test dgunakan untuk mengukur peningkatan pemahaman dan wawasan penggunaan E-learning proses pembelajaran secara online. Posttest merupakan bentuk evaluasi akhir dari materi yang telah diberikan di hari itu dengan tujuan untuk melihat apakah peserta memahami dan mengerti dari materi yang sudah diajarkan(Istiani and Retnoningsih 2015; Pratiwi, Ardianti, and Kanzunnudin 2018).

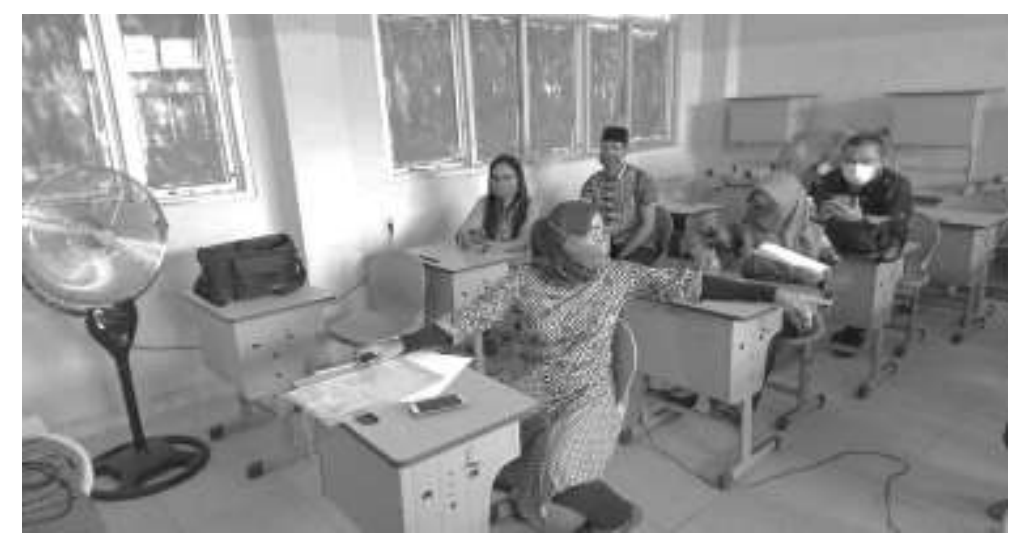

Gambar 3. Pembagian Kuesioner Evaluasi Kegiatan

\section{HASIL DAN PEMBAHASAN}

Indikator penilaian pre-test dan post-test menggunakan skala linkert dengan 5 tingkatan penilaian, yaitu : 
Tabel 1 Keterangan skala penilaian

\begin{tabular}{ll}
\hline Skala Nilai & Keterangan \\
\hline 1 = Sangat Tidak setuju & Tidak mengetahu Teori dan praktik \\
2 = Tidak Setuju & Tidak mengetahui secara teoritis \\
$3=$ Ragu-Ragu & Ragu-ragu \\
$4=$ Setuju & Mengetahui secara teoritis \\
$5=$ Sangat Setuju & Mengetahui secara teori dan praktik \\
\hline
\end{tabular}

Indicator penilaian diberlakukan untuk 10 pertanyaan pada pre-test dan post-test, adapun pertanyaan tersebut seputar E-learning google classroom yang tampak pada table 2 .

Tabel 2 Pertanyaan kuesioner pretest dan post-test

No. Pertanyaan

Google Classroom adalah layanan web gratis, yang dikembangkan oleh Google untuk

1 sekolah, yang bertujuan untuk menyederhanakan membuat, mendistribusikan, dan menilai tugas tanpa harus bertatap muka.

2 Google Classroom merupakan salah satu media pembelajaran yang bisa digunakan pada masa pandemi.

Google Classroom merupakan media pembelajaran online atau istilahnya adalah kelas

3 online sehingga dapat memudahkan guru dalam membuat, membagikan serta mengelompokkan setiap tugas.

Dengan menggunakan google classroom guru bisa membuat kelas maya, mengajak siswa gabung dalam kelas, memberikan informasi terkait proses KBM, memberikan materi ajar yang bisa dipelajari siswa baik berupa file materi maupun video pembelajaran, memberikan tugas kepada siswa, membuat jadwal pengumpulan tugas dan lain-lain.

5 Google Classroom Sangat Mudah Digunakan Untuk Pemula dalam mengelola pemberian dan penilaian tugas siswa.

6 Tampilan yang dimiliki oleh Google Classroom sangat menarik.

7 Google classroom merupakan media e-learning yang dapat digunakan dimana saja.

8 Dengan menggunakan Google classroom murid bisa menerima dan mengumpulkan tugas langsung di classroom, begitu juga para guru.

9 Dengan google classroom kita bisa memulai rapat video, menambahkan materi tugas, seperti Video Youtube, Survei Google form, dan item lainnya dari google drive.

10 Dengan memanfaat google classroom orang tua siswa dapat memonitoring hasil belajar siswa secara langsung.

Hasil pretest yang telah dilakukan, didapatkan bahwa banyak guru sudah mengetahui Elearning google classroom, tetapi hanya bebatas pengetahuan dasar belum sampai tahap cara penggunaan dan bagaimana cara memanfaatkan google classroom untuk kegiatan belajar online. Hal ini ditunjukan banyaknya yang memiliki penilaian setuju dimana represetasi setuju adalah mengetahui secara teoritis. Dari 15 audience yang memilih nilai setuju sebanyak 47,33 \%, 29,33\% mengetahui secara teoritis dan praktik dan sisanya $23,33 \%$ ragu-ragu atau kurang mnegetahui. Tingkatan hasil pre-test ini bisa di lihat pada gambar 4 . 


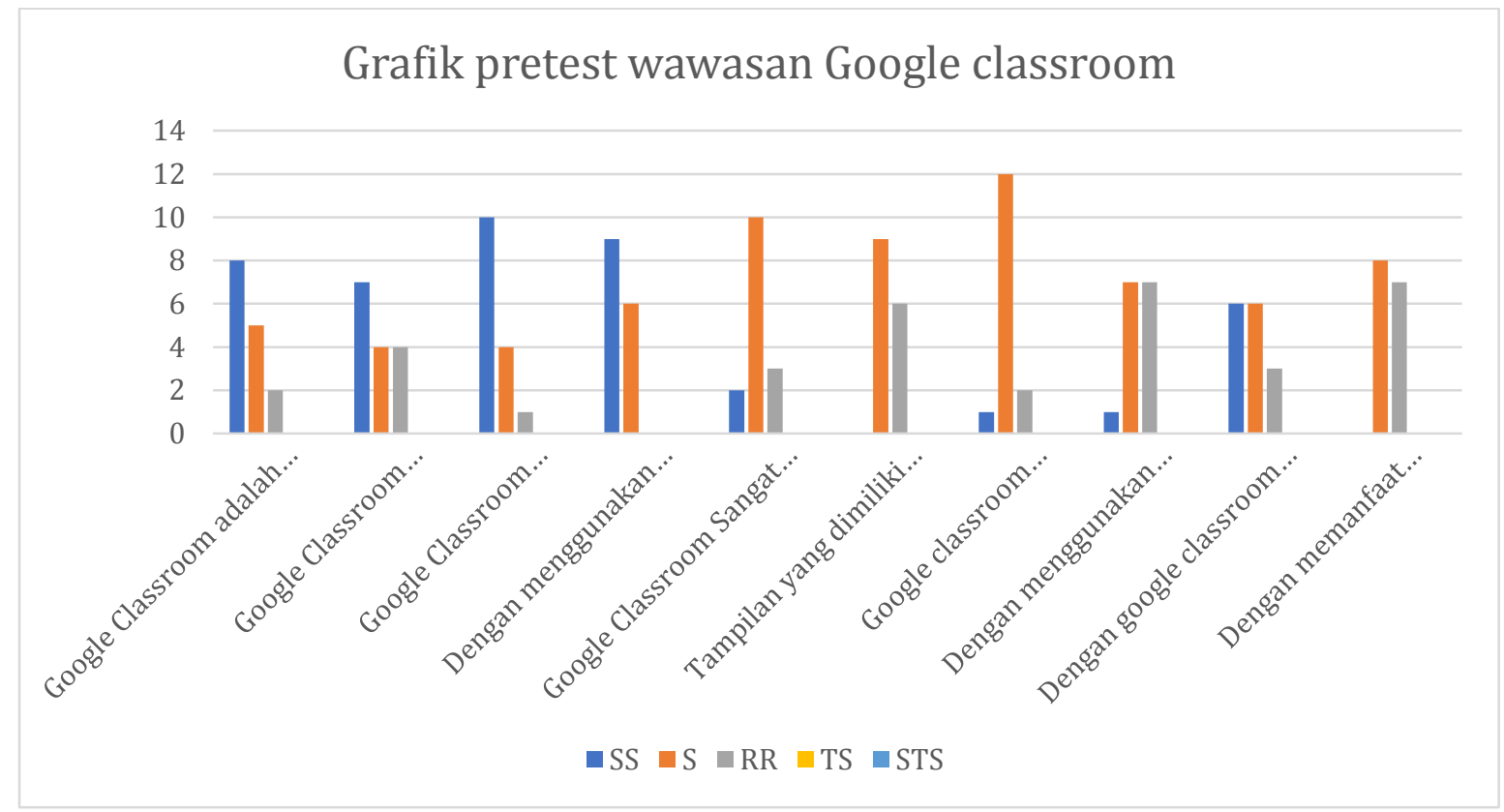

Gambar 4. Grafik pretest wawasan pemahaman dan penguasaan google classroom

Setelah dilakukan sosialisasi dan pelatihan penggunaan google classroom kemudian tim melakukan pengujian ulang dengan cara menebar kuesioner post-test kepada para peserta. Hasil dari kuesioner post-test ternyata mengami peningkatan, dimana banyak guru sudah menguasai secara teoritis dan praktik dari E-learning google classroom hal ini ditunjukan dengan meningkatnya jumlah audience yang memilih nilai sangat setuju yang merepresentasikan nilai menguasai teori dan praktik sebanyak $56 \%$, kemudian yang memilih setuju yang merepresentasi menguasai secara teori sebanyak 35,33\% dan sisanya ragu-ragu sebnyak 8,66\% hal ini dipengarui oleh factor usia guru yang sudah di atas usia 40\%. Peningkatan penguasaan penggunaan elearning google classroom dipengaruhi oleh usia guru yang berada di bawah $40 \%$ yang berdampak pada mudahnya beradaptasi terhadap teknologi dan perubahan pola mengajar.

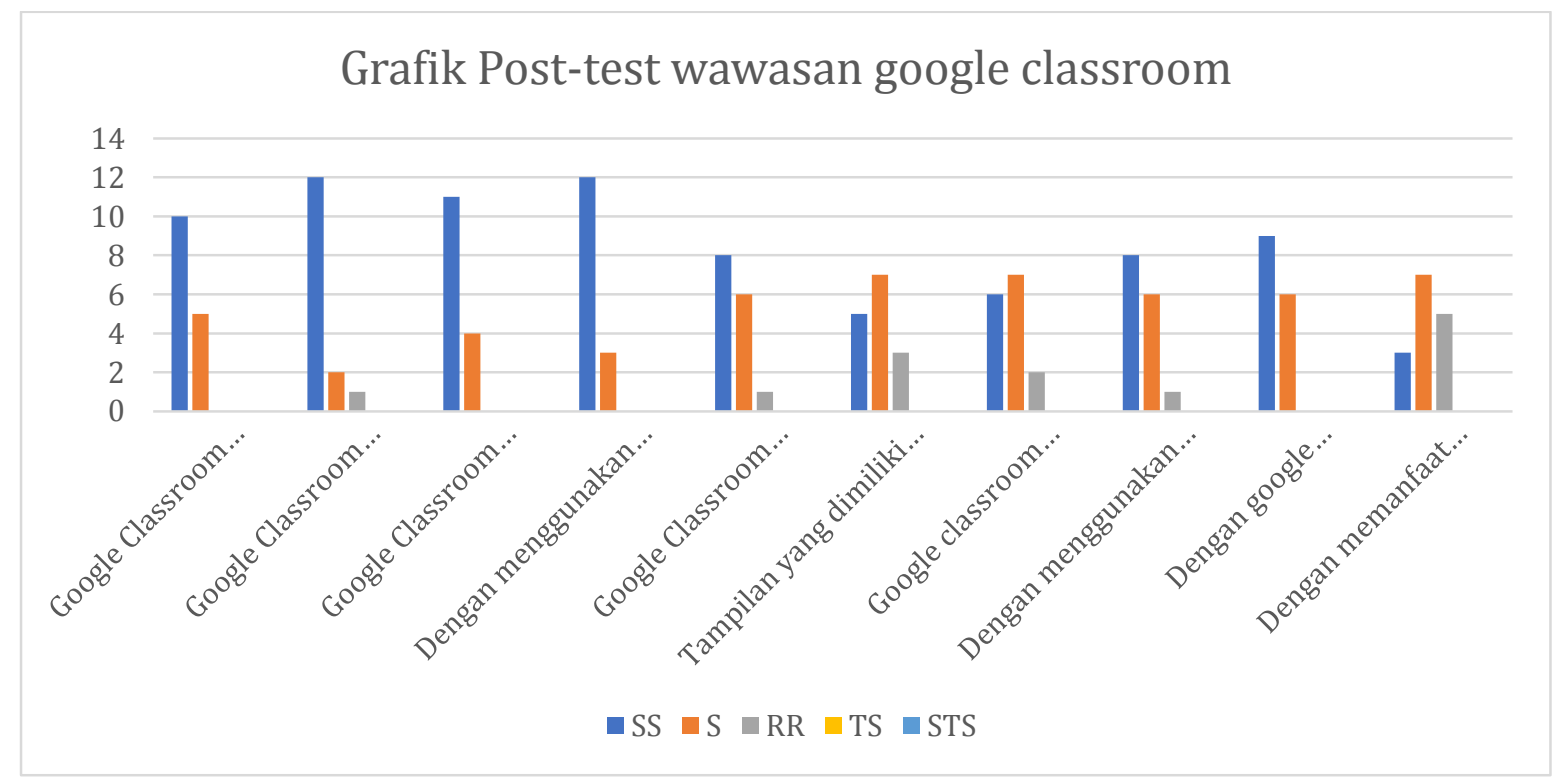

Gambar 5. Grafik Post-test wawasan pemahaman dan penguasaan google classroom 


\section{KESIMPULAN}

Adapun kesimpulan yang didapat dalam kegiatan pengabdian yang dilaksanakan oleh tim pelaksana kegiatan pengabdian terhadap mitra dalam hal ini adalah SD Negeri 170 Palembang, antara lain :

1. Kegiatan pengabdian ini dapat memberikan pengetahuan dan keterampilan bagi guru SD Negeri 170 Palembang tentang penggunaan aplikasi Google Classroom sebagai sarana pendukung bekerja dari rumah saat pandemi Covid-19.

2. Metode yang digunakan dalam penyampaian materi pengabdian adalah pelatihan, praktik dan Tanya jawab dengan tetap menerapkan protokol kesehatan Covid-19.

3. Sebelum dan seudah melakukan kegiatan pengabdian tim pelaksana kegiatan pengabdian melakukan penyebaran kuesioner berupa pretest dan post-test

4. Dari hasil kegiatan didapatkan terjadi penigkatan penguasaan teori dan praktik penggunaan google classroom untuk kegiatan pengajaran secara daring. Hal ini di tunjukan dari hasil posttest terjadi peningkatan sebanyak 56\% memilih sangat setuju, 35,33\% memilih setuju, dan $8,66 \%$ memilih ragu-ragu, jika dibandingkan dengan nilai pretest menunjukan sebanyak 29,33\% memilih sangat setuju, 47,33\% memilih setuju dan 23,33\% memilih ragu-ragu.

5. Peningkatan penguasaan penggunaan e-learning google classroom dipengaruhi oleh usia para guru. Usia guru dibawah 30 tahun memilih sangat setuju dikarenakan kemudahan dalam memahami dan penguasaan cara penggunaan perangkat lunak e-learning dan kemudahan dalam beradaptasi dengan perangkat lunak tersebut sedangkan sisanya dipengaruhi oleh usia guru yang berada di atas 40 tahun dikarenakan kesulitan dalam penguasaan dan beradaptasi dengan perangkat lunak tesebut.

\section{UCAPAN TERIMA KASIH}

Penulis mengucapkan terima kasih kepada STMIK Palcomtech yang telah memberikan dukungan penuh dalam bentuk materil dan non materil dan terima kasih kepada para mitra dalam hal ini SD Negeri 170 Palembang yang telah memfasilitasi tim pelaksana pengabdian dalam bentuk ruang dan fasilitas serta kesediaan para guru yang meluangkan waktu untuk bisa mengikuti kegiatan pengabdian ini.

\section{DAFTAR PUSTAKA}

Ali, Lalu Usman, and Muhammad Zaini. 2020. "Pemanfaatan Program Aplikasi Google Classroom Sebagai Upaya Meningkatkan Motivasi Dan Prestasi Belajar Mahasiswa Pada Perkuliahan Dasar-Dasar Kependidikan." Society 11(1):27-34.

Amalina, Amalina. 2020. "Pembelajaran Matematika Anak Usia Dini Di Masa Pandemi COVID-19 Tahun 2020." Jurnal Obsesi : Jurnal Pendidikan Anak Usia Dini 5(1):538.

Angraini, Shinta Dwi. 2020. "No Title." Palembang Jadi Zona Merah Covid-19 Lagi, Berikut Rincian Status Kabupaten/Kota Di Sumsel. Retrieved June 20, 2020 (https://www.tribunnews.com/regional/2020/06/30/palembang-jadi-zona-merah-covid19-lagi-berikut-rincian-status-kabupatenkota-di-sumsel.).

Effendy, Ilham. 2016. "Pengaruh Pemberian Pre-Test Dan Post-Test Terhadap Hasil Belajar Mata Diklat HDW.DEV.100.2.a Pada Siswa SMK Negeri 2 Lubuk Basung." Jurnal Ilmiah Pendidikan 1(2):81-88.

Gunawan, Fransiskus Ivan, and Stefani Geima Sunarman. 2017. "Pengembangan Kelas Virtual Dengan Google Classroom Dalam Keterampilan Pemecahan Masalah (Problem Solving) Topik Vektor Pada Siswa Smk Untuk Mendukung Pembelajaran." Prosiding Seminar Nasional 
Etnomatnesia 340-48.

Istiani, Rina Munawar, and Amin Retnoningsih. 2015. "Pemanfaatan Lingkungan Sekolah Sebagai Sumber Belajar Menggunakan Metode Post To Post Pada Materi Klasifikasi Makhluk Hidup." Journal of Biology Education 4(1):70-80.

Kemdikbud. 2020. "No Title." Panduan Penyelenggaraan Pembelajaran Pada Tahun Ajaran Dan Tahun Akademik Baru Di Masa Covid-1. Retrieved July 17, 2020 (https://www.kemdikbud.go.id/main/blog/2020/06/panduan-penyelenggaraanpembelajaran-pada-tahun-ajaran-dan-tahun-akademik-baru-di-masa-covid19/).

Kurniawan, Bayu, Agus Purnomo, and . Idris. 2020. "Pelatihan Penggunaan Aplikasi Google Classroom Sebagai Upaya Peningkatan Pembelajaran Online Bagi Guru Matapelajaran IPS MTs Di Kota Malang." International Journal of Community Service Learning 4(1):1.

Pratiwi, Ika Ari, Sekar Dwi Ardianti, and Moh. Kanzunnudin. 2018. "Peningkatan Kemampuan Kerjasama Melalui Model Project Based Learning (PjBL) Berbantuan Metode Edutainment Pada Mata Pelajaran Ilmu Pengetahuan Sosial." Refleksi Edukatika : Jurnal Ilmiah Kependidikan 8(2):177-82.

Ratu, Dian, Ayu Uswatun, and Hascaryo Pramudibyanto. 2020. "Pendidikan Dalam Masa Pandemi Covid-19." Jurnal Sinestesia 10(1):41-48.

Santosa, Farah Heniati, Habibi Ratu Perwira Negara, and Samsul Bahri. 2020. "Efektivitas Pembelajaran Google Classroom Terhadap Kemampuan Penalaran Matematis Siswa." Jurnal Pemikiran Dan Penelitian Pendidikan Matematika (JP3M) 3(1):62-70.

Sri Harini Ekowati, Wahyu Tri Widyastuti, Wahyu Tri Widyastuti, and Asti Purbarini. 2020. "Implementasi Kahoot Dalam Pembelajaran Bahasa Prancis Pada Masa Pandemi Covid-19 Di SMK DKI Jakarta." Dinamisia : Jurnal Pengabdian Kepada Masyarakat 4(4):723-29.

Wong, Ruth. 2020. "When No One Can Go to School: Does Online Learning Meet Students' Basic Learning Needs?" Interactive Learning Environments 3:1-17. 